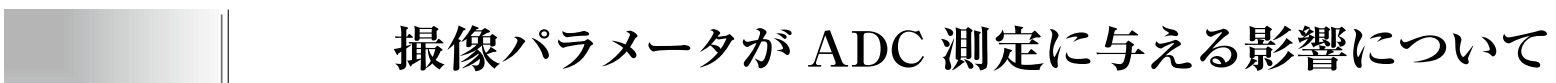

原 著

\author{
2010 年 3 論文 3 受付 \\ 論文受理
}

2010 年 6 月21日

Code No. 261
尾崎正則 ${ }^{1)}$ - 小倉明夫 ${ }^{2)} \cdot$ 室伊三男 ${ }^{3)}$ ・宮地利明 ${ }^{4)} \cdot$ 田村隆行 ${ }^{5)}$ 高橋光幸 ${ }^{6)}$ ・王井 司 $^{7)}$-丹治 一8) 高橋順士 ${ }^{9)}$ ・滝沢 修10)

1 ) 北里大学医療衛生学部医療工学科

2)京都市立病院放射線科

3) 東海大学医学部付属病院放射線技術科

4) 金沢大学医学部医学系研究科保健学専攻

5) 広島原爆障害対策協議会健康管理増進センタ一放射線科

6) 国家公務員共済組合連合会横浜栄共済病院放射線科

7) 大阪大学医学部附属病院医療技術部放射線部門

8) 財団法人仁泉会医学研究所北福島医療センター画像センター

9)国家公務員共済組合連合会虎の門病院放射線部

10)シーメンス旭メディテック株式会社マーケティング本部

\section{緒 言}

近年, magnetic resonance imaging (MRI) 検査にお いて頭部や躯幹部の拡散強調画像 (diffusion weighted imaging: DWI)の臨床応用が急速に広がり，急性期脳 梗塞の評価や悪性腫瘍の検出などに盛んに行われて いる1〜5)。 また，DWIから得られた信号よりみかけの
拡散係数 (apparent diffusion coefficient: ADC)が算出 可能である.ADC 值は DWIによる画像診断と比べ 定量的な評価が可能になるためADC 值による悪性 腫瘍の鑑別診断などの研究論文が散見される ${ }^{6 \sim 11)}$. $\mathrm{ADC}$ 值の算出方法には 2 点法と多点法が存在する. どちらの算出方法もそれぞれ利点, 欠点が存在する

\title{
Influence of Imaging Parameters on the Measurement of Apparent Diffusion Coefficient
}

\section{Masanori Ozaki, ${ }^{1)}$ Akio Ogura, ${ }^{2)}$ Isao Muro, ${ }^{3)}$ Tosiaki Miyati, 4) Takayuki Tamura,5) Mitsuyuki Takahashi, ${ }^{\text {) }}$ Tsukasa Doi, ${ }^{7)}$ Hajime Tanji, ${ }^{8)}$ Junji Takahashi, ${ }^{9}$ and Osamu Takizawa ${ }^{10}$}

1) School of Allied Health Sciences, Kitasato University

2) Department of Radiology, Kyoto City Hospital

3) Department of Radiology, Tokai University Hospital

4) Division of Health Sciences, Kanazawa University Graduate School of Medical Science

5) Department of Radiology, Hiroshima Atomic Bomb Casualty Council, Health Management \& Promotion Center

6) Department of Radiology, Federation of National Public Service and Affiliated Personnel Mutual Aid Associations, Yokohama Sakae Kyousai Hospital

7) Department of Radiology, Osaka University Hospital

8) Imaging Center, Jinsenkai Medical Foundation. Northern Fukushima Medical Center

9) Department of Radiological Technology, Federation of National Public Service Personnel Mutual Aid Associations, Toranomon Hospital

10) Siemens Asahi Medical Technologies Ltd. Marketing Division, R\&C Group

Received March 3, 2010; Revision accepted June 21,2010; Code No. 261

\section{Summary}

The apparent diffusion coefficient (ADC) values are calculated by using signal intensity in diffusionweighted images (DWIs) with two or more different b-value. Therefore, the signal to noise ratio (SNR) of DWI with higher b-value may have a big influence on the measured ADC value. We examined the influence of the imaging parameters on the calculated ADC values. The SNR of DWI increased by using a larger voxel size, by means of a decreased number of matrix, an increased slice thickness, and an increased field of view (FOV). However, when the number of excitations was increased to improve the SNR of DWI, the signal intensity of background noise was observed to be slightly increased. It was suggested that the consistency of measured ADC was not preserved when the signal of the DWIs with higher b-value dropped close to the noise level.

Key words: apparent diffusion coefficient, backgroud noise, signal to noise ratio, diffusion weighted image 
が, 現在は撮像時間が短く, 簡便な 2 点法が主流に なっている. 2 点法における ADC 值は

$$
\mathrm{ADC} \text { values }=-\ln (\mathrm{SI}(\mathrm{b} 1) / \mathrm{SI}(\mathrm{b} 2)) /(\mathrm{b} 1-\mathrm{b} 2)
$$

上記式(1)より算出される.

$\mathrm{ADC}$ 值算出には異なる複数の $\mathrm{b}$ 值から得られた信 号強度より算出されるため, 信号杂隹音比 (signal to noise ratio: SNR)に影響を与える撮像パラメータが ADC 值の測定に影響を与える可能性がある. 傾斜磁 場変動による振動の影響によるADC 值の変化や ${ }^{12)}$, $\mathrm{ADC}$ 測定における呼吸の影響13), b 值および, 測定 する対象物の $\mathrm{T}_{1}$ 值, $\mathrm{T}_{2}$ 值によっては repetition time (TR), echo time(TE)が ADC 值に影響を与えるとい う報告 ${ }^{14)}$ はあるが, その他の撮像パラメータが $\mathrm{ADC}$ 值に与える影響に関しては検討されていない. しか し, 呼吸などの bulk motion や $\mathrm{b}$ 值, TR, TE 以外に SNRに直接影響を与える撮像パラメータの設定に よっては ADC 值の信頼性が低下することが予想され る. また, 最近では生体での ADC 值の bi-exponential decay に関する研究や15,16), q-space imaging ${ }^{17,18) な ~}$ ど非常に高い $\mathrm{b}$ 值で測定する研究が盛んに行われて おり, SNRが測定されるADC 值に与える影響を把 握しておく必要性が高いと考える.

そこで今回われわれは SNR に直接影響を与える撮 像パラメータが測定される ADC 值に与える影響につ いて検討を行ったので報告する.

\section{1. 方 法}

\section{1-1 使用装置}

MRI 装置は SIGNA HDxt 1.5 T ver15.0(GE Healthcare 社製, Milwaukee), 受信コイルは送受信型 QD HEAD コイルを用いた。 ファントムは $20 \mathrm{~cm}$ 径の円筒状で中 性洗剤(界面活性剂 18\%, 安定化剤, $\mathrm{T}_{1}$ 值：620 ms, $\mathrm{T}_{2}$ 值 : $321 \mathrm{~ms}$ )を封入したファントムを用いた。

\section{1-2 撮像条件}

撮像パルスシーケンスは spin echo 型 single-shot echo-planar imaging 法を用いた。 基準とした撮像パ ラメータは TR10000 ms, TE138〜 $152 \mathrm{~ms}$, 受信バン ド幅 $\pm 250 \mathrm{kHz}$, field of view $(\mathrm{FOV}) 30 \mathrm{~cm}$, スライス 厚 $5 \mathrm{~mm}$, マトリクス数 (周波数エンコード数 $\times$ 位相 エンコード数) $128 \times 128, \mathrm{~b}$ 值 $0 \sim 8000 \mathrm{~s} / \mathrm{mm}^{2}$, 拡散測 定時間 $56.2 \mathrm{~ms}$, である.

1-3 加算回数, スライス厚, FOV, マトリクス 数が ADC 值に与える影響について

基本撮像パラメータに対して SNRに直接影響を与
える撮像パラメータのうち加算回数を $1,4,16$, スラ イス厚を $2.5 \mathrm{~mm}, 5 \mathrm{~mm}, 10 \mathrm{~mm}, F O V を 21.2 \mathrm{~cm}$, $30 \mathrm{~cm}, 42.4 \mathrm{~cm}$, マトリクス数を $64 \times 64,128 \times 128$, $256 \times 256$ におのおの変化させて撮像を行い, ファント ムの信号強度, 標準偏差 (standard deviation: SD), お よび，バックグラウンドの信号強度および SDを測定 し，ADC 值および SNR を算出した.

\section{1-4 ADC 值および SNR の算出方法}

$\mathrm{ADC}$ 值は実験結果から得られた $b=0 \mathrm{~s} / \mathrm{mm}^{2}$ および 各 $\mathrm{b}$ 值の信号強度から, 式(1)を用いて算出した。

SNR 測定は 1 回測定法 ${ }^{19)}$ を採用し,

$$
\mathrm{SNR}=(4-\pi / 2)^{1 / 2} \times \mathrm{SI}(\mathrm{b}) / \mathrm{SDair}(\mathrm{b})
$$

$\mathrm{SI}(\mathrm{b})$ : 各 $\mathrm{b}$ 值におけるファントムの region of interest (ROI) 内信号強度の平均值

SDair(b) : 各 b 值における画像の四隅のバックグラ ウンド測定 ROI 内の標準偏差の平均值

上記式(2)を用いて算出した。

\section{2. 結 果}

$\mathrm{b}$ 值を変化させた場合, どの撮像パラメータを変化 させた場合も低い $\mathrm{b}$ 值では一定の ADC 值を示し, b 值がより高くなるにしたがい ADC 值が小さくなる傾 向があった(Fig. 1). 加算回数を変化させた場合, 得 られる ADC 值に変化はなかった(Fig. 1a). スライス 厚を変化させた場合，スライス厚が厚くなるにしたが いより高いb 值まで一定の ADC 值が得られた(Fig. 1b).FOVを変化させた場合, FOVが大きくなるに したがいより高い $\mathrm{b}$ 值まで一定の ADC 值が得られた (Fig. 1c)。マトリクス数を変化させた場合, マトリク ス数が小さくなるにしたがいより高い b 值まで一定の ADC 值が得られた(Fig. 1d).

SNR については，加算回数を変化させた場合，加 算回数を大きくするにしたがい，より高いSNR が得 られた(Fig. 2a). スライス厚を変化させた場合, スラ イス厚が厚くなるにしたがいより高いSNRが得られ た(Fig. 2b). FOVを変化させた場合, FOVが大きく なるにしたがいより高いSNR が得られた(Fig. 2c). マトリクス数を変化させた場合, マトリクス数が小さ くなるにしたがいより高い SNR が得られた(Fig. 2d).

Fig. 3〜6に各撮像パラメータを変化させた場合の ファントムの信号強度およびバックグラウンドの信号 強度と $\mathrm{b}$ 值の関係のグラフを示す. 各グラフのエラー バーはファントムの信号強度を測定したROI 内の $\mathrm{SD} \times 2$ を示す. Fig. 3〜6のすべてのグラフにおいて, ファントムの信号強度は $\mathrm{b}$ 值が大きくなるにしたがい 

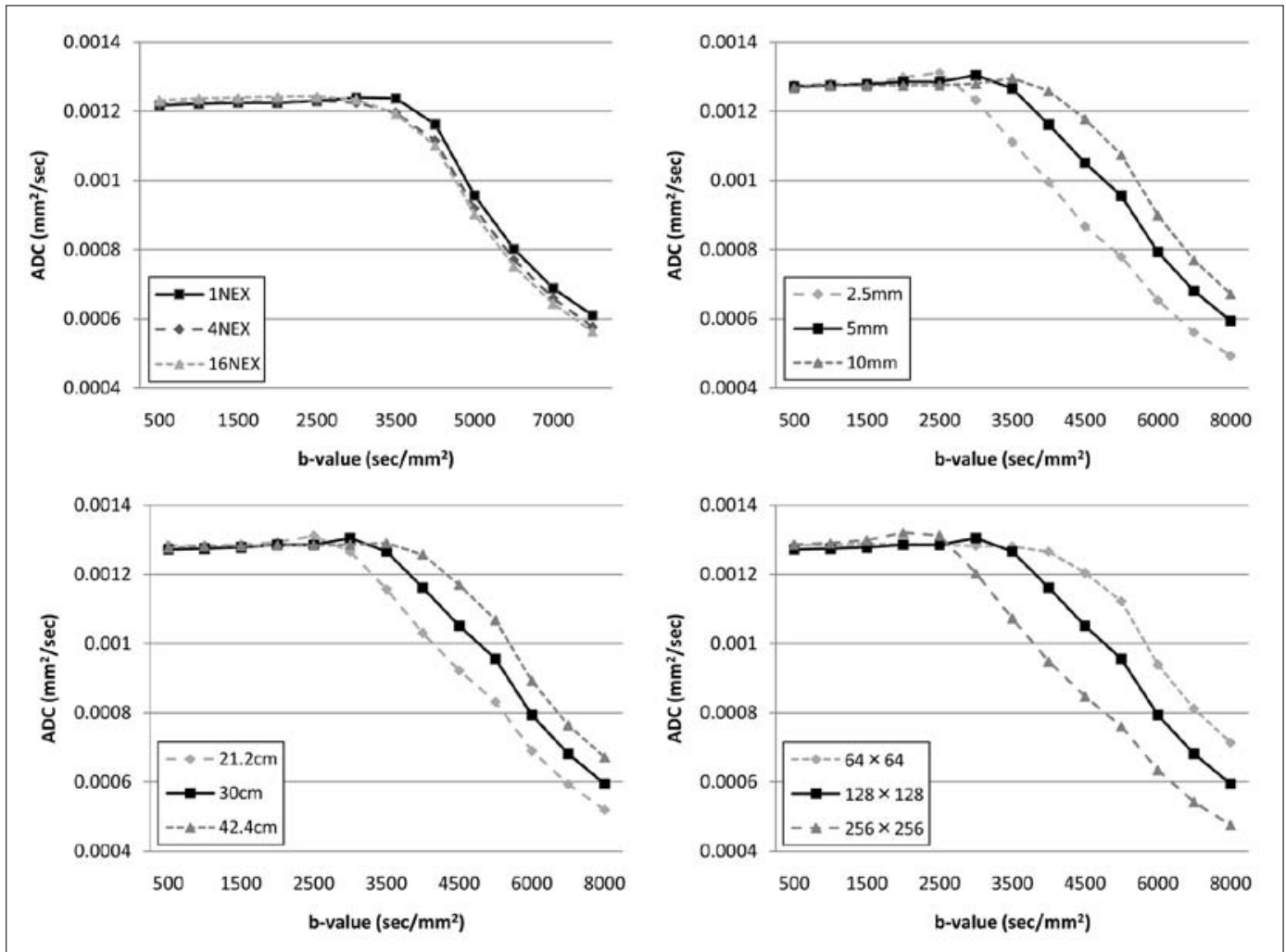

Fig. 1 Relation between b-value changes and ADC values in each imaging parameter.
(a) When number of excitations changed.
(b) When slice thickness changed.
(c) When FOV changed.
(d) When matrix changed.

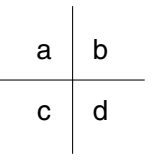

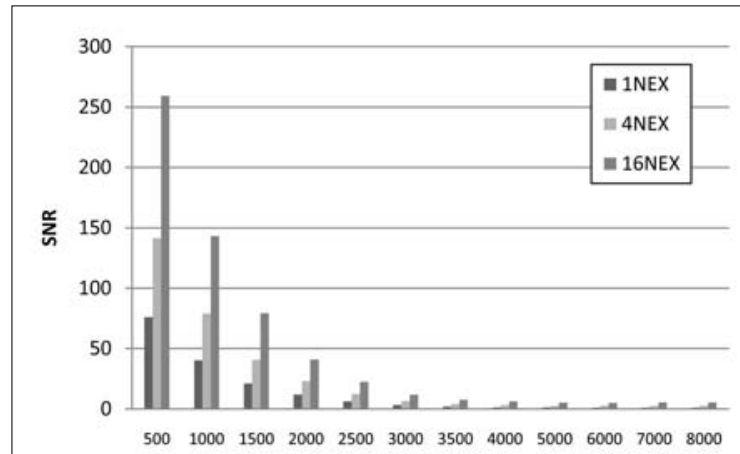

b-value $\left(\mathrm{sec} / \mathrm{mm}^{2}\right)$

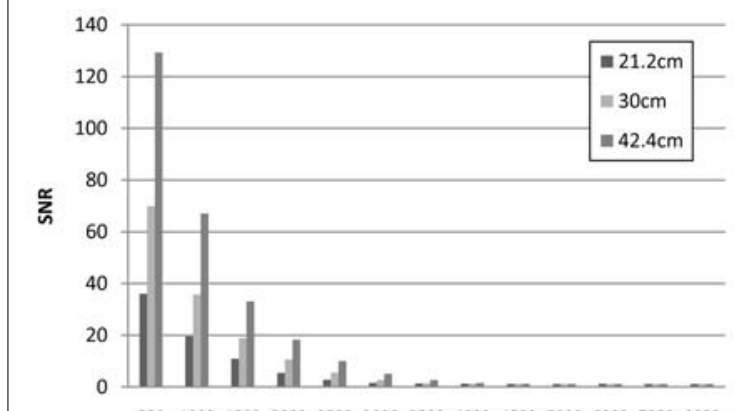

b-value (sec/ $\left./ \mathrm{mm}^{2}\right)$

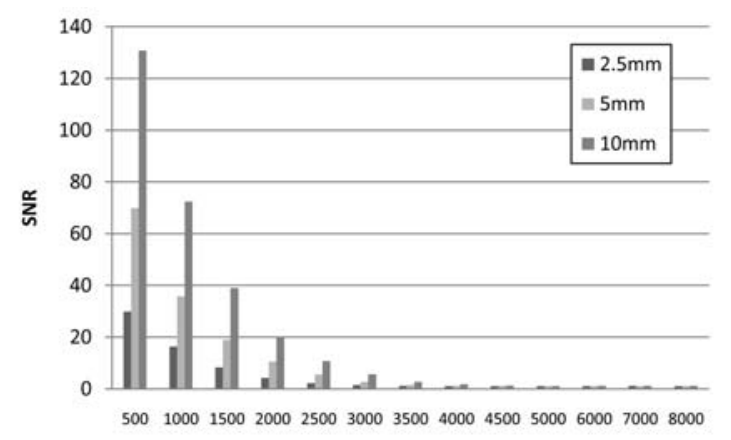

b-value $\left(\mathrm{sec} / \mathrm{mm}^{2}\right)$

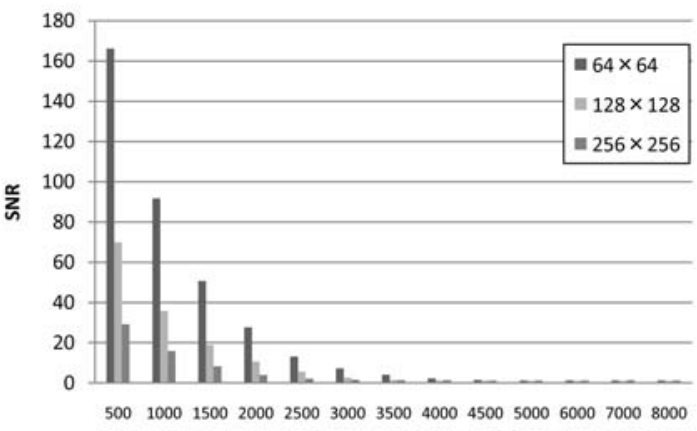

b-value $\left(\mathrm{sec} / \mathrm{mm}^{2}\right)$

Fig. 2 Relation between b-value changes and SNRs in each imaging parameter.
(a) When number of excitations changed
(b) When slice thickness changed.
(c) When FOV changed.
(d) When matrix changed. 
低下していき，バックグラウンドの信号強度 $(\mathrm{BG}(\mathrm{b}))$ はb 值によらずほぼ一定の值を示した。加算回数を 変化させた場合，加算回数を上げるにしたがい，わ ずかであるが BG(b)が高くなった(Fig. 3). スライス 厚を変化させた場合，スライス厚が厚くなるにしたが い BG(b)が低くなっていった(Fig. 4). FOVを変化さ せた場合，FOVが大きくなるにしたがい $\mathrm{BG}(\mathrm{b})$ が低 くなっていった(Fig. 5). マトリクス数を変化させた 場合，マトリクス数が小さくなるにしたがい $\mathrm{BG}(\mathrm{b})$ が 低くなっていった(Fig. 6).

どの撮像パラメータにおいても, SI(b)-2×SD(Fig. 3〜6の各エラーバー下側の值)が $\mathrm{BG}(\mathrm{b})$ を下回らない 值を示す $\mathrm{b}$ 值 (Fig. 3〜6の各グラフの点線の垂直線 部以下の $\mathrm{b}$ 值)のときに安定した ADC 值が得られた。

\section{3. 考 察}

スライス厚, FOV, マトリクス数を変化させること によって SNR および BG(b)が変化し，SNR が高くな るほど，また， BG(b)が低くなるほど，より高い b 值 まで一定の ADC 值を得ることができた，FOV やマト リクス数を変化させた場合は echo planar imaging(EPI) のエンコード時間が変化するために TE が変化し最大
で $14 \mathrm{~ms}$ 程度の差がでた。 TEの変化による SNRの 変化が得られた結果に影響を与えている可能性も考 えられたが，SNRの変化はFOVやマトリクス数の変 化に伴う理論值に近い值であり, 今回の TEの変化 では TEによる影響はないと言える。また，今回使用 したファントムは液体であることから，制限拡散はな いと考えられる。 そして自由拡散下での測定ではb 值によって ADC 值は変化しない。したがって今回の 結果から ADC 值測定と SNRには密接な関係がある ことがわかる。しかし，SNRに影響を与える撮像パ ラメータである加算回数を大きくした場合には, SNR が高くなるにもかかわらず， BG(b)はわずかではある が高くなり, 一定の ADC 值が得られる $\mathrm{b}$ 值は変化し なかった. 加算回数の変化によって, このような結果 になった要因としてDWIの再構成アルゴリズムに関 係があると考えられる。通常の MR 画像では加算回 数が 1 より大きい場合, k-space上で加算した後に フーリエ変換を行い実画像に変換する。しかし,

DWI の場合, k-space上で加算を行うと拡散のラン ダム性が平均化されてしまうため正確に拡散が画像 に反映されなくなる。そのため，各画像をフーリエ変 換し実画像に変換後に加算を行っている．加算の手

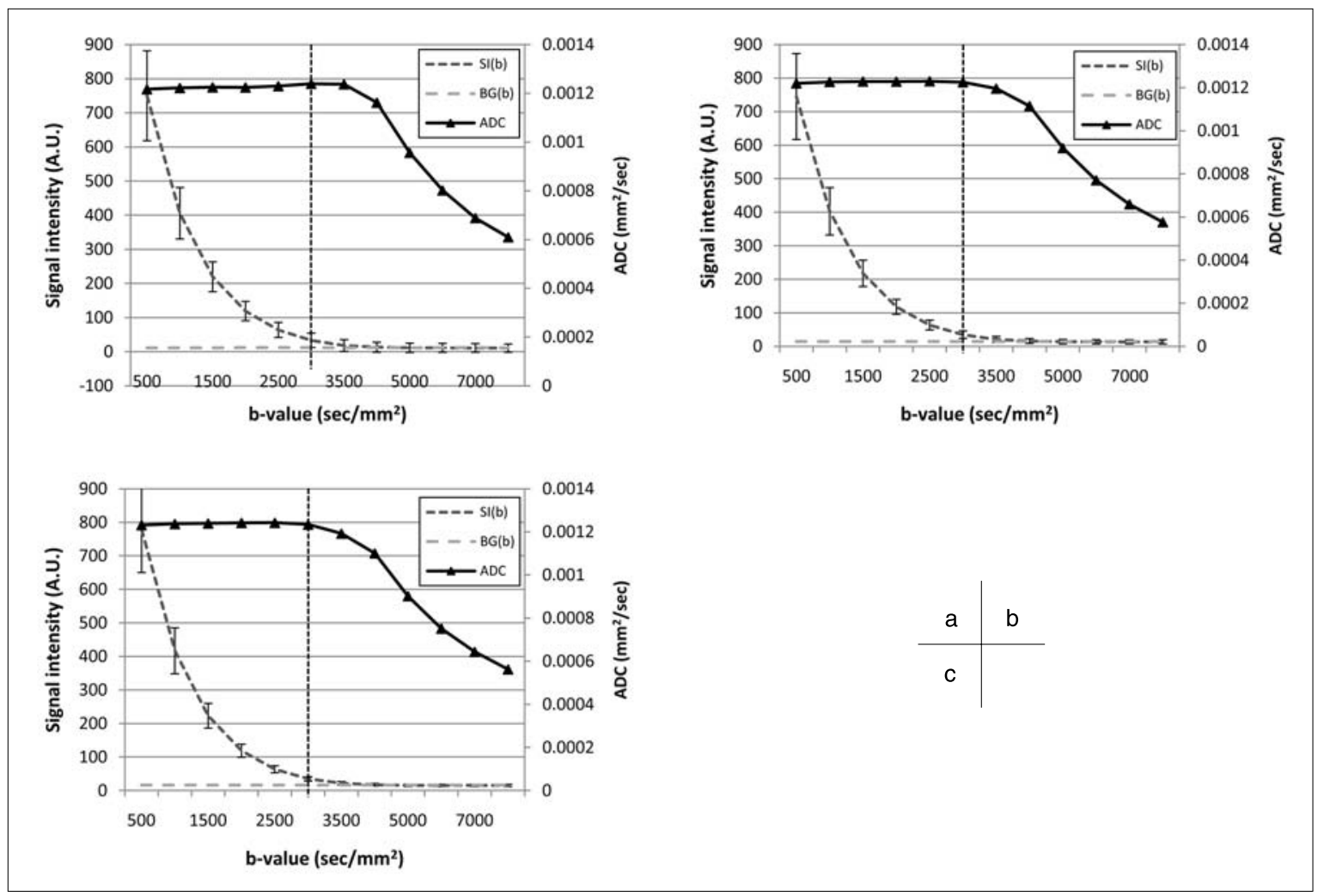

Fig. 3 Relation between $b$ values and ADC values, signal intensity of phantom and background noise, when number of excitations changed.
(a) number of excitations: 1.
(b) number of excitations: 4 .
(c) number of excitations: 16 . 


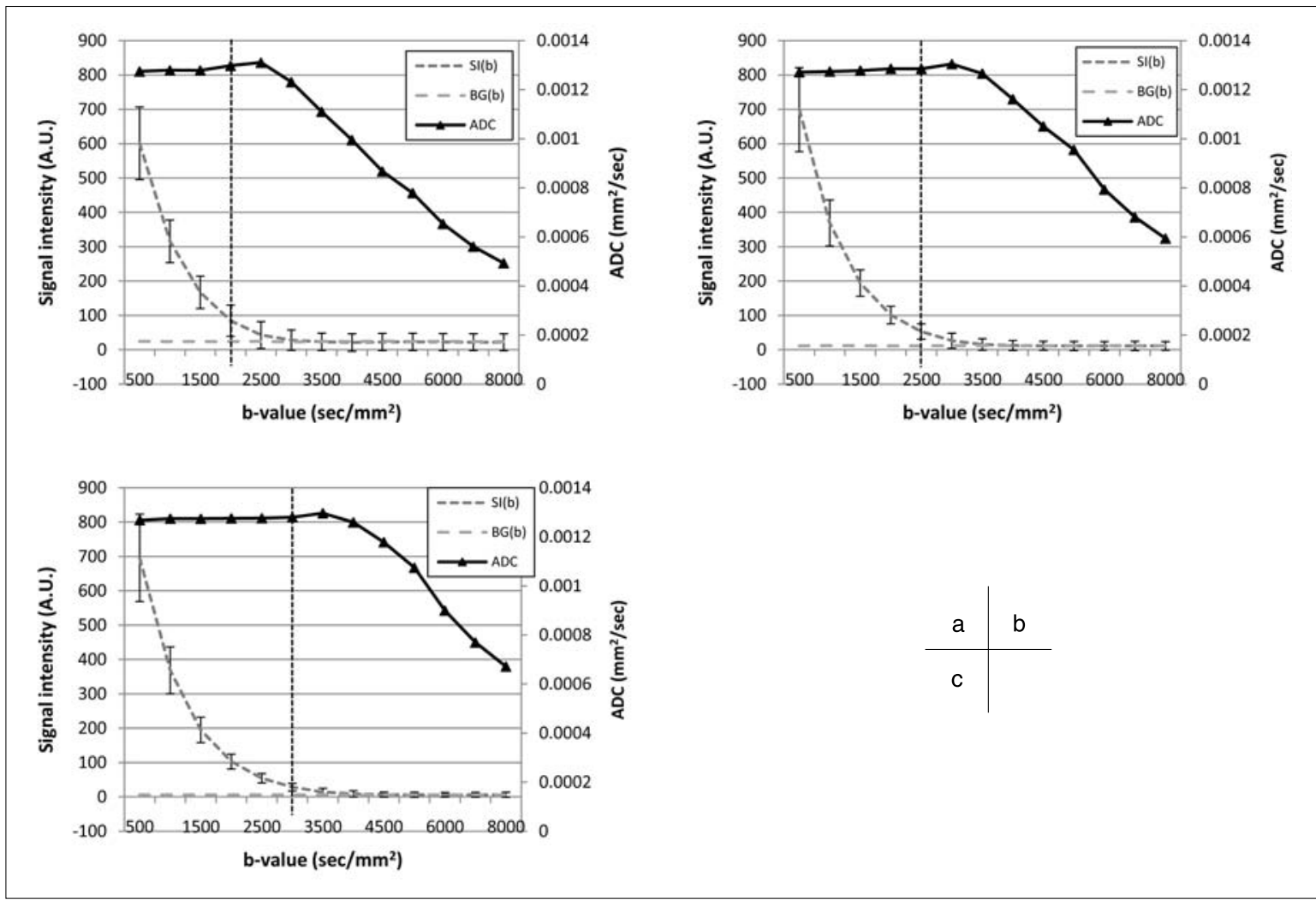

Fig. 4 Relation between b values and ADC values, signal intensity of phantom and background noise, when slice thickness changed.
(a) slice thickness: $2.5 \mathrm{~mm}$.
(b) slice thickness: $5 \mathrm{~mm}$.
(c) slice thickness: $10 \mathrm{~mm}$.

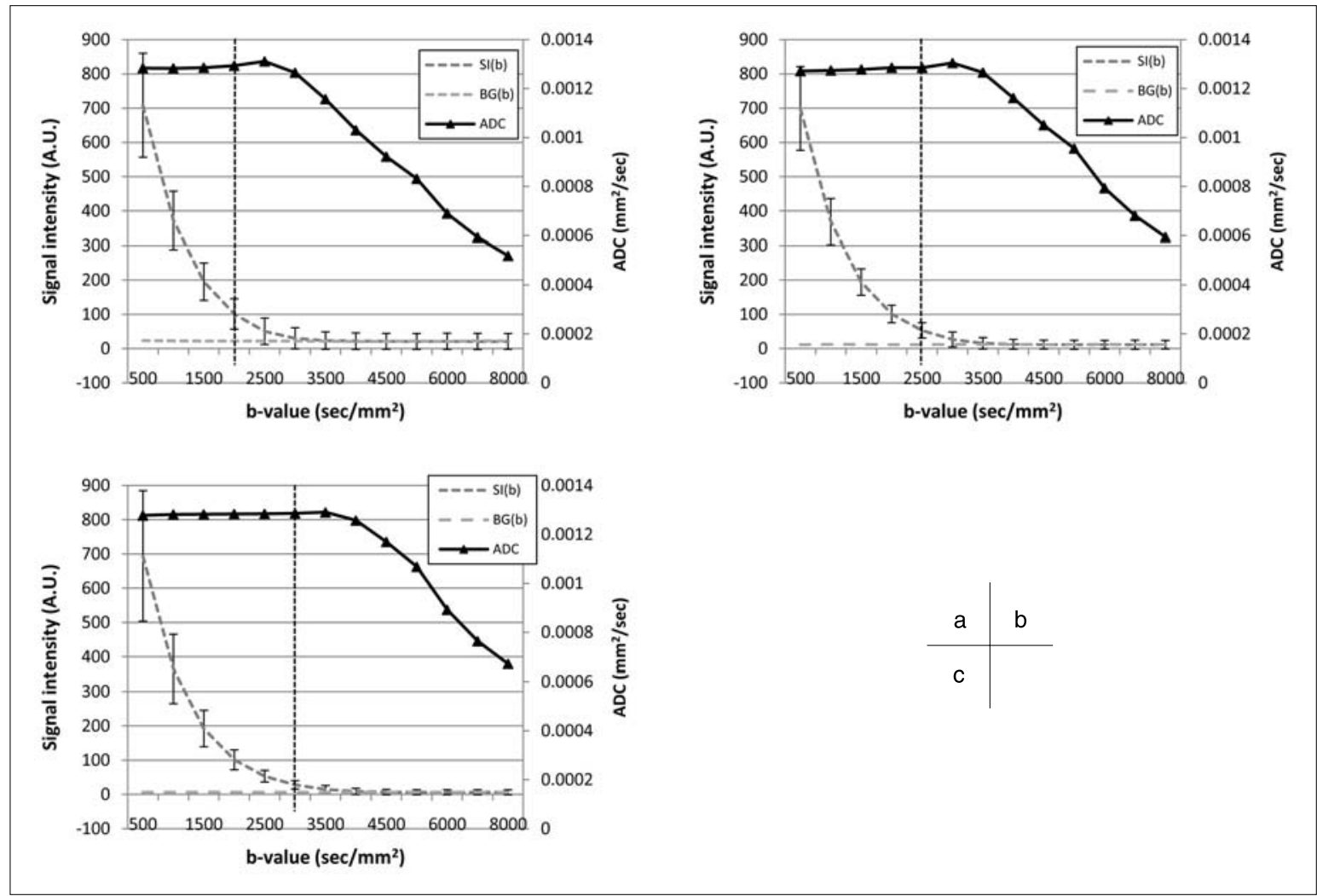

Fig. 5 Relation between $b$ values and ADC values, signal intensity of phantom and background noise, when FOV changed.
(a) FOV: $21.2 \mathrm{~cm}$.
(b) FOV: $30 \mathrm{~cm}$.
(c) FOV: $42.4 \mathrm{~cm}$. 

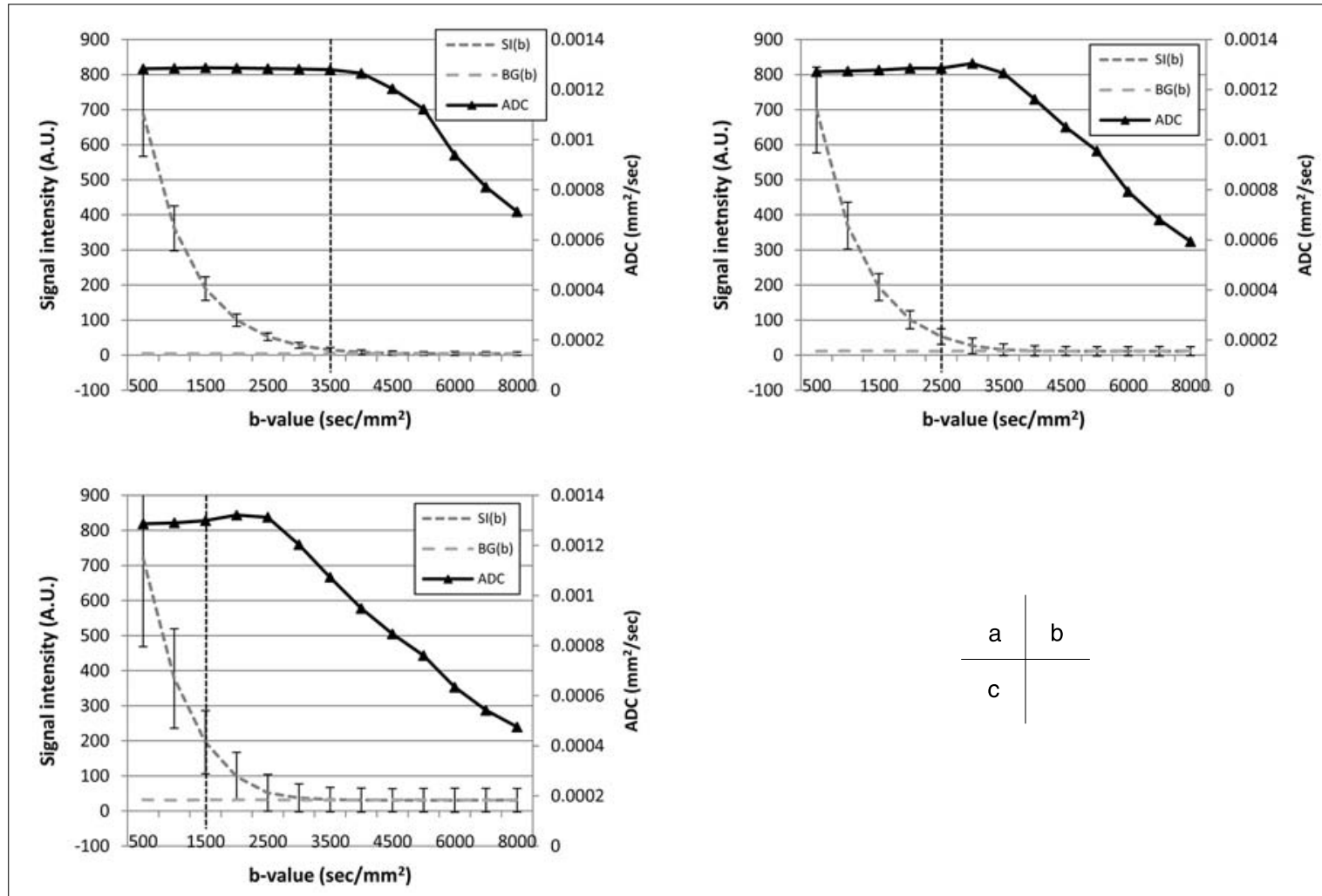

Fig. 6 Relation between b values and ADC values, signal intensity of phantom and background noise, when matrix changed.
(a) matrix: $64 \times 64$
(b) matrix: $128 \times 128$.
(c) matrix: $256 \times 256$.

法は, motion probing gradient (MPG) 軸の合成には相 乗平均, 加算回数による加算は相加平均を行ってい る. 実画像で加算処理を行うことによって, pixel by pixelにおける加算になってしまうため, バックグラウ ンド領域の信号のバラつきは減少するが, 信号レベ ルそのものは変化しない. しかし, 相加平均と相乗平 均を比較した場合, 相加平均のほうが相乗平均より 大きな信号強度に算出されてしまう. そのため, 加算 回数を上げることによって, 相加平均を使用する加算 の割合が，相乗平均を使用する MPG 軸合成の割合 に比べ大きくなってしまうために相加平均の影響が強 くなり, SNR は向上するものの, BG(b)の平均值がわ ずかではあるが大きくなったと考える. そのため, 加 算回数を上げてもバックグラウンドと測定する対象の 信号強度差がほとんど変化せず, DWI では加算回数 を大きくしても正しい ADC 值の測定可能な $\mathrm{b}$ 值も変 化しなかったと言える，換言すれば，加算回数 1 で 正しい ADC 值を測定できない対象物は加算回数を 上げても測定できないことを意味する.

また Fig. 3〜6から, SI (b)-2×SD が BG(b)を下回 らないときに安定した ADC 值が得られている. MRI
の有信号部分が正規分布に従っていると考えると SNRの低い場合, 対象物の信号分布の広い範囲に バックグラウンドノイズが上乗せされてしまうため, 本来の信号強度より高い值を示してしまう。また低 SNR 下での magnitude image は信号のバラつきのう ち，負の信号部分が正方向に折りかえってしまうた め, ファントムの信号の平均值がさらに高くなってし まう。その結果, ADC 值が本来の值より小さく算出 されてしまったと考えられる。

以上の結果から安定した ADC 值を測定するにあ たり， $\mathrm{SI}(\mathrm{b})-2 \times \mathrm{SD}>\mathrm{BG}(\mathrm{b})$ を満たす撮像パラメータで 撮像することが必要条件であると言える。しかし，現 在臨床での検査では parallel imaging を使用すること が一般的である. parallel imaging を使用した場合， 画像を展開する際に無信号部分は０にしてしまうた めに BG(b)を測定することができない。また, parallel imaging を用いた画像のノイズ分布が受信コイル の感度に依存するなど, 今回示した指標は適用でき ない. parallel imaging を使用した際の評価は今後の 課題であると考える. 


\section{4. 結 語}

以上より， SNR が測定される ADC 值に影響を与 えることが確認できた。 また拡散強調画像のパルス シーケンスにおいて，加算回数を上げることで SNR は向上するものの, BG(b)が低下しないことが確認で きた.そして, ADC值を測定する際にはSI(b)-2 $\times \mathrm{SD}>\mathrm{BG}(\mathrm{b})$ を満たす撮像パラメータで撮像すること が必要条件であり, 今回の結果は ADC 值を用いた研 究において ADC 值の信頼性を担保させる指標の一 つになり得る.

\section{謝 辞}

本研究は, 平成 $20 \cdot 21$ 年度日本放射線技術学会, 学術委員会調査研究班 (MRI の ADC 值測定精度に 関する研究班)での検討をまとめたものである。関係 各位に感謝いたします。またパルスシーケンス開発お よび実験に際し，多大なるご助言をいただいた GE ヘルスケア・ジャパン株式会社 平野勝也氏, 京都大 学大学院医学研究科放射線医学講座 藤本晃司先生 ならびに北里大学病院放射線部 MR 検査室スタッフ 一同にこの場をお借りして厚く御礼申し上げます.

\section{参考文献}

1) Bammer R, Keeling SL, Augustin M, et al. Improved diffusion-weight single-shot echo-planar imaging(EPI) in stroke using sensitivity encoding(SENSE). Magn Reson Med 2001; 46(3): 548-554.

2) Takahara T, Imai Y, Yamashita T, et al. Diffusion weighted whole body imaging with background body signal suppression(DWIBS): technical improvement using free breathing, STIR and high resolution 3D display. Radiation Medicine 2004; 22(4): 275-282.

3) Warach S, Gaa J, Siewert B, et al. Acute humanstroke studied by whole brain echo planar diffusion-weighted magnetic resonance imaging. Ann Neurol 1995; 37(2): 231-241.

4) Ichikawa T, Haradome H, Hachiya J, et al. Diffusionweighted MR imaging with a single-shot echoplanar sequence: detection and characterization of focal hepatic lesions. AJR Am J Roentgenol 1998; 170(2): 397-402.

5) Nasu K, Kuroki Y, Nawano S, et al. Hepatic metastases: diffusion-weighted sensitivity-encoding versus SPIOenhanced MR imaging. Radiology 2006; 239(1): 122-130.

6) Woodhams R, Matsunaga K, Kan S, et al. ADC Mapping of benign and malignant breast tumors. Magn Reson Med Sci 2005; 4(1): 35-42.

7) Moteki T, Ishizuka H. Diffusion-weighted EPI of cystic ovarian lesions: evaluation of cystic contents using apparent diffusion coefficients. J Magn Reson Imaging 2000; 12(6): 1014-1019.

8) Sato C, Naganawa S, Nakamura T, et al. Differentiation of noncancerous tissue and cancer lesions by apparent diffusion coefficient values in transition and peripheral zone of the prostate. J Magn Reson Imaging 2005; 21(3): 258-262.

9) Yoshikawa T, Kawamitsu H, Mitchell DG, et al. ADC measurement of abdominal organs and lesions using parallel imaging technique. AJR Am J Roentgenol 2006; 187(6): 1521-1530.

10) Nakayama T, Yoshimitsu K, Irie H, et al. Diffusionweighted echo-planar MR imaging and ADC mapping in the differential diagnosis of ovarian cystic masses: usefulness of detecting keratinoid substances in mature cystic teratomas. J Magn Reson Imaging 2005; 22(2): 271-278.

11) Eida S, Sumi M, Sakihama N, et al. Apparent diffusion coefficient mapping of salivary gland tumors: prediction of the benignancy and malignancy. AJNR Am J Neuroradiol 2007; 28(1): 116-121.

12）小倉明夫，前田富美江，宮井 明，他．傾斜磁場変動に よる振動が拡散強調画像に与える影響について. 日放技 学誌 2006; 62(4): 565-569.

13）室伊三男, 高原太郎, 堀江朋彦, 他. 自由呼吸下一躯体 部拡散強調画像における動きの影響について. 日放技学 誌 2005;61(11): 1551-1558.

14) Ogura A, Hayakawa $K$, Miyati $T$, et al. Imaging parameter effects in apparent diffusion coefficient determination of magnetic resonance imaging. Eur J Radiol (IN PRESS).

15) Mulkern RV, Zengingonul HP, Robertson RL, et al. Multi-component apparent diffusion coefficients in human brain: relationship to spin-lattice relaxation. Magn Reson Med 2000; 44(2): 292-300.

16) Riches SF, Hawtin K, Charles-Edwards EM, et al. Diffusion-weighted imaging of the prostate and rectal wall: comparison of biexponential and monoexponential modelled diffusion and associated perfusion coefficients. NMR Biomed 2009; 22(3): 318-325.

17) Assaf Y, Ben-Bashat D, Chapman J, et al. High b-value q-space analyzed diffusion-weighted MRI: application to multiple sclerosis. Magn Reson Med 2002 Jan; 47(1): 115-126.

18) Assaf Y, Mayzel-Oreg O, Gigi A, et al. High b value q-space-analyzed diffusion MRI in vascular dementia: a preliminary study. J Neurol Sci 2002 Nov 15; 203-204: 235-9.

19) Kaufman L, Kramer DM, Crooks LE, et al. Measuring signal-to-noise ratios in MR imaging. Radiology 1989; 173(1): 265-267. 
Fig. 1 各撮像パラメータにおける $\mathrm{b}$ 值と ADC 值の関係
(a)加算回数を変化させた場合
（b）スライス厚を変化させた場合
(c)FOVを変化させた場合
（d）マトリクスを変化させた場合

Fig. 2 各撮像パラメータに抢ける b 值と SNR の関係
(a)加算回数を変化させた場合
（b）スライス厚を変化させた場合
(c)FOV を変化させた場合
（d）マトリクスを変化させた場合

Fig. 3 加算回数を変化させた場合の $\mathrm{b}$ 值と ADC 值掞よびファントムの信号強度, バックグラウンドの信号強度の関係
(a)加算回数 : 1
(b)加算回数 : 2
(c) 加算回数 : 16

Fig. 4 スライス厚を変化させた場合の $\mathrm{b}$ 值と ADC 值およびファントムの信号強度, バックグラウンドの信号強度の関係
(a)スライス厚 : $2.5 \mathrm{~mm}$
(b) スライス厚 : $5 \mathrm{~mm}$
(c)スライス厚 : $10 \mathrm{~mm}$

Fig. 5 FOV を変化させた場合の b 值と ADC 值およびファントムの信号強度, バックグラウンドの信号強度の関係
(a)FOV : $21.2 \mathrm{~cm}$
(b) FOV : $30.0 \mathrm{~cm}$
(c) FOV : $42.4 \mathrm{~cm}$

Fig. 6 マトリクスを変化させた場合の b 值と ADC 值およびファントムの信号強度，バックグラウンドの信号強度の関係
(a)マトリクス : $64 \times 64$
(b)マトリクス : $128 \times 128$
(c)マトリクス : $256 \times 256$ 